\title{
Variation of total amount of phenolic compounds, radical scavenging activity and volatile compounds of Liriodendron tulipifera L. and Ginkgo biloba L. leaves extracts during different vegetation periods
}

\author{
Jurgita Mikašauskaitè ${ }^{1}$, \\ Ona Ragažinskien $\dot{e}^{2}$, \\ Audrius Maruška ${ }^{1 \star}$ \\ ${ }^{1}$ Department of Biochemistry \\ and Biotechnologies, \\ Vytautas Magnus University, \\ Vileikos 8, LT-44404 Kaunas, \\ Lithuania \\ ${ }^{2}$ Department of Medicinal Plants, \\ Vytautas Magnus University, \\ Kaunas Botanical Garden, \\ Žilibero 6, LT-46324 Kaunas, \\ Lithuania
}

There is a lack of research focussing on Liriodendron tulipifera L. and Ginkgo biloba L. introduced in Lithuania. Moreover, extensive comparative phytochemical studies of these two relict plants have not yet been carried out. Therefore the aim of this study was a complex comparative analysis of biologically active compounds of these two plants introduced in Lithuania, using spectrophotometric, chromatographic and mass spectrometric techniques. To the authors' knowledge there is no data published yet on comparative analysis of Liriodendron tulipifera L. and Ginkgo biloba L. introduced in different countries. Volatile compounds, radical scavenging activity, total amount and composition of phenolic compounds and flavonoids accumulated in leaves of these plants during different vegetation periods were determined. Remarkable differences of quantitative and qualitative composition of phenolic compounds have been determined in different vegetation periods in different plants. The highest total amount of phenolic compounds was in Liriodendron tulipifera L. leaves collected at the start of seed ripening vegetation period (12 $300 \mathrm{mg} \mathrm{RE} / 100 \mathrm{~g}$ ). In Ginkgo biloba L. the highest amount of phenolic compounds was determined at the end of leaves growth (5 $990 \mathrm{mg} \mathrm{RE} / 100 \mathrm{~g}$ ). The qualitative and quantitative analysis of phenolic compounds revealed the presence of rutin, chlorogenic and sinapic acids in extracts of Liriodendron tulipifera L. and rutin with chlorogenic acid in extracts of Ginkgo biloba L. Composition and amount of volatile compounds were dependent on the plant species and vegetation period. The highest concentration of volatile compounds was found in the leaves of Liriodendron tulipifera L. at the end of flowering.

Key words: Liriodendron tulipifera L., Ginkgo biloba L., radical scavenging activity, vegetation periods, DPPH, solid phase microextraction

* Corresponding author. E-mail: a.maruska@gmf.vdu.lt 


\section{INTRODUCTION}

Plant extracts are traditionally used as medicines for treatment of diseases and widely used as topical applications for anti-aging and wound-healing [1]. Introduced plant species that became successful invaders appear often more vigorous and taller than their conspecifics in the native range [2].

Ginkgo biloba L. is a monotypic genus native to China and extracts of leaves of this plant have been well known for many centuries for its biological activities. The major components in Ginkgo biloba L. are flavonoids such as quercetin, kaempferol, rutin and robinin [3]. These chemical constituents have free radical scavenging properties and function as antioxidants. The flavoglycosides contained in Ginkgo biloba L. are compounds of the most medicinal interest and have exhibited remarkable pharmacological capabilities $[4$, $5,6,7]$. The terpene compounds of Ginkgo biloba L., which include the ginkgolides and the bilobalides, help to lessen inflammation by inhibiting platelet activating factor (PAF) in the blood [8]. This activity improves blood circulation. PAF plays a certain role in diseases such as atherosclerosis, asthma, heart attacks and strokes. Extract of Ginkgo biloba L. (Ginkgoaceae) has been extensively used in a variety of cardiovascular and cerebrovascular diseases such as ischemia, dementia and depression $[9,10]$. In traditional Chinese medicine Ginkgo biloba L. has been used for many centuries. Nowadays extracts of Ginkgo biloba L. are one of the most globally used medicines, particularly in the USA and Europe [11, 12]. Extracts of Ginkgo biloba L. are appreciable alternative medicine and are used for treatment and prevention of various pathologies. These extracts are suggested as additional preparations by the medicine [13]. There are a lot of compounds of pharmacological interest in the extracts of Ginkgo biloba L., such as terpenoids, polyphenols, alkylphenols, alylphenols, organic acids, carbohydrates, fatty acids and lipids, inorganic salts and amino acids. It was assessed that methanolic extract of Ginkgo biloba L. possesses a more effective antioxidant capacity than acetone extract, depending on the extraction solvent effect. High total amount of phenolic compounds of the methanolic extract correlates with the antioxidant properties [14].

Liriodendron tulipifera $\mathrm{L}$. is a fast growing hardwood tree species native to the North America, which is used for wood and pulp products $[15,16]$. Earlier investigations on the chemical constituents of Liriodendron tulipifera L. dealt with sesquiterpenes [17] and several alkaloids [18]. Liriodendron tulipifera L. (Magnoliaceae) was found to show inhibitory activity towards farnesyl protein transferase (FPT-ase). Bioassay-guided fractionation of the methanolic extract resulted in the isolation of lipiferolide, an inhibitor of FPT-ase. This compound can be of interest in the development of effective therapeutic agents for the treatment of cancer [19]. Compounds present in Liriodendron tulipifera L. can play an assistant role in the anti-oxidant and antityrosinase effects. Components of Liriodendron tulipifera L. are promising chemopreventive agents against melanoma metastasis in clinical applications [20]. There have been found ca. 40 secondary metabolites, a considerable part of which are alkaloids, in the extracts of Liriodendron tulipifera L. [21]. One of Liriodendron tulipifera L. alcaloids - glaudine was included into a group of substances being tested against the gypsy moth (Lymantria dispar), although it was found that the toxin is weak and ineffective for eradication of larvae [22]. However, little is known about other bio-functions of this plant. Sesquiterpenes lactones from Liriodendron tulipifera L. have appetite-inhibiting properties [22]. Liriodenine derivatives have been reported to be cytotoxic to many cancer lines including breast cancer, lung cancer and hepatoma cells. Additionally, the anti-proliferative effects of liriodenine and its derivatives may mediate the apoptosis and ROS production within these cells $[23,24,25]$. 


\section{MATERIALS AND METHODS}

\section{Chemicals}

Methanol (99.8\% pure) was acquired from Chempur (Poland). Folin-Ciocalteu's phenol reagent, syringic acid, acetonitrile, 2, 2-diphenyl-1-picrylhydrazyl (DPPH), quercetin and rutin (95\% pure) were obtained from Sigma-Aldrich (USA). Sodium carbonate 99\% pure was obtained from Reachem (Slovakia). Gallic, chlorogenic, synapic, ferrulic acids, hexamethylenetetramine (96\% pure) and naringenin were from Fluka (USA). Caffeic, protocatechuic, o-coumaric acids were purchased from Acros Organics (USA). Aluminium chloride $\left(\mathrm{AlCl}_{3}\right), 98 \%$ pure, was purchased from Roth (Germany). Sodium acetate, 99.2\% pure, was obtained from Fisher (USA). Acetonitrile, $99.8 \%$ pure, was purchased from Baker (Netherlands). Acetic acid, $99 \%$ pure and sodium dihydrogen phosphate, $99 \%$ pure, were purchased from Lachema (Czech Republic). Trifluoroacetic acid, 98\% pure, was from Merck (Germany).

\section{Plant materials and extraction}

Leaves of two plants, Ginkgo biloba L. and $\mathrm{Li}$ riodendron tulipifera $\mathrm{L}$. were collected from Kaunas Botanical Garden of Vytautas Magnus University in 2012 and all were identified prior to extraction (Table 1).
The dried leaves were crushed using mortar and pestle. Dry plant material (500 mg) was soaked in $20 \mathrm{ml}$ of aqueous methanol (75\%) and extracted in orbital shaker for $15 \mathrm{~h}$ at room temperature. The extract was filtered through paper and $0.22 \mu \mathrm{m}$ membrane filters to remove mechanical particles. The filtrates were stored at $4{ }^{\circ} \mathrm{C}$ for further analysis. The same extract of every plant sample was used to carry out all chromatographic and spectrophotometric determinations.

\section{Determination of total amount of phenolic compounds}

The method reported by Stankevičius et al. [26] was slightly modified and used to determine the total amount of phenolic compounds (TAP) in the extracts. The plant extracts were diluted 10 times with 75\% (vol.) methanol prior to analysis. $100 \mu$ of each diluted sample was mixed with $3 \mathrm{ml}$ of $3.3 \%$ sodium carbonate solution and $100 \mu \mathrm{l}$ of Folin-Ciocalteu's reagent $(2 \mathrm{~N})$ was added. After incubation for $30 \mathrm{~min}$ at room temperature the absorbance at $760 \mathrm{~nm}$ was measured using spectrophotometer Spectronic 1201 (Milton Roy, USA). The linear calibration curve ranged between 0.01 and $1.00 \mathrm{mg} / \mathrm{ml}\left(\mathrm{R}^{2}=0.9936\right)$. Mean values were calculated from three colorimetric reactions carried out parallel for every sample. Results were expressed as rutin equivalents (RE) in $\mathrm{mg} / 100 \mathrm{~g}$ of dry plant material.

Table 1. Samples of leaves investigated

\begin{tabular}{c|ccc|c}
\hline \multirow{2}{*}{ Plant } & $\begin{array}{c}\text { Vegetation } \\
\text { period }\end{array}$ & $\begin{array}{c}\text { Marking } \\
\text { of vegetation } \\
\text { period }\end{array}$ & $\begin{array}{c}\text { Colour } \\
\text { of leaves }\end{array}$ & $\begin{array}{c}\text { Number of } \\
\text { sample }\end{array}$ \\
\hline \multirow{3}{*}{ Ginkgo biloba $\mathrm{L}}$. & End of leaf growth & $\mathrm{A}_{3}$ & Green & 1 \\
\cline { 2 - 5 } & End of leaf growth & $\mathrm{A}_{3}$ & Green & 2 \\
\cline { 2 - 5 } & Seed ripening & $\mathrm{V}$ & Green & 3 \\
\cline { 2 - 5 } & $\begin{array}{c}\text { Leaf } \\
\text { discolouration }\end{array}$ & $\mathrm{L}_{1}$ & $\begin{array}{c}\text { Green and } \\
\text { yellow }\end{array}$ & 4 \\
\hline \multirow{2}{*}{$\begin{array}{c}\text { Endiodendron } \\
\text { tulipifera } \mathrm{L} .\end{array}$} & End of flowering & $\mathrm{Z}_{3}$ & Green & 5 \\
\cline { 2 - 5 } & $\begin{array}{c}\text { Start of seed } \\
\text { ripening }\end{array}$ & $\mathrm{Z}_{3}$ & Green & 6 \\
\cline { 2 - 5 } & First ripened seeds & $\mathrm{V}_{1}$ & Green & 7 \\
\hline
\end{tabular}




\section{Determination of total amount of flavonoids}

The total amount of flavonoids (TAF) was determined using the method described by Urbonavičiūte et al. [27]. This method is based on complexation of phenolic compounds with $\mathrm{Al}$ (III) providing an absorbance maximum at $407 \mathrm{~nm} .80 \mu \mathrm{l}$ of each extract in methanol was mixed with $1920 \mu \mathrm{l}$ of a reaction mixture (60 $\mathrm{ml}$ of methanol (100\%), $3 \mathrm{ml}$ acetic acid (33\%), $12 \mathrm{ml}$ of hexamethylenetetramine (5\%), $9 \mathrm{ml}$ of aluminium chloride (10\%) and $60 \mathrm{ml}$ of bidistilled water). The absorbance at $407 \mathrm{~nm}$ was read after 30 min incubation at ambient temperature. The calibration curve ranged between $0.01-1.00 \mathrm{mg} / \mathrm{ml}\left(\mathrm{R}^{2}=0.9980\right)$. All determinations were carried out in triplicate from 3 parallel analyses. TAF was expressed in rutin equivalents (RE), mg per $100 \mathrm{~g}$ of dry plant material.

\section{DPPH radical scavenging assay}

DPPH radical scavenging activity (RSA) was performed according to the method reported in [28] with some modifications. The plant extracts were diluted 50 times with $75 \%$ (vol.) methanol prior to analysis. $7 \mu$ of sample or methanol (blank) were added to $3.000 \mathrm{ml}$ of methanolic solution of $100 \mathrm{mM} \mathrm{DPPH}$ and vortexed. After $15 \mathrm{~min}$, absorbance at $515 \mathrm{~nm}$ was measured using spectrophotometer Spectronic 1201 (Milton Roy, USA). The calibration curve ranged between $0.05-0.25 \mathrm{mg} /$ $\mathrm{ml}\left(\mathrm{R}^{2}=0.9920\right)$. All measurements were performed in triplicate and the result was an average of three values. The DPPH RSA was calculated in rutin equivalents (RE), mg per $100 \mathrm{~g}$ of dry material.

\section{High performance liquid chromatography using electrochemical detection}

For separation and electrochemical detection of extracted compounds high performance liquid chromatography (HPLC) gradient system (ESA, USA) was used. The method was described earlier in [26]. For analysis, $20 \mu \mathrm{l}$ of sample was injected by means of model 542 auto sampler. High-pressure gradient was formed using two 582 HPLC pumps. Reversed-phase C-18 column $80 \times 4.6 \mathrm{~mm}$, particle size $3 \mu \mathrm{m}, 120 \AA$ pore size (ESA, USA) was used for separations. Chromatograms were acquired by means of model 5600 CoulArray electrochemical detector with the array of cells with the potentials set at 300,500, 700 and $900 \mathrm{mV}$. Flow rate of the mobile phase was $0.75 \mathrm{ml} / \mathrm{min}$. Elution was performed using two component mobile phase. Solvent A was composed of $50 \mathrm{mM}$ sodium dihydrogen phosphate $(\mathrm{pH} 3)$ with $1 \%$ (vol) additive of methanol. Solvent B was a mixture of $100 \mathrm{mM}$ sodium dihydrogen phosphate, $\mathrm{pHv}$, acetonitrile and methanol (30:60:10 v/v). Phenolic compounds were eluted using the following gradient: $10 \%$ of B at $0 \mathrm{~min} ; 100 \%$ of $\mathrm{B}$ at $46 \mathrm{~min} ; 10 \%$ of $\mathrm{B}$ at $57 \mathrm{~min}$ and $10 \%$ of $B$ at $63 \mathrm{~min}$. Flow rate was set at $0.25 \mathrm{ml} / \mathrm{min}$. The quantities of the identified compounds are expressed in mg per $100 \mathrm{~g}$ of dry plant material.

\section{Solid phase micro extraction conditions}

For headspace solid phase micro extraction (SPME), a divinylbenzene/carboxene/polydimethylsiloxane (DVB/CAR/PDMS) coated fiber (SUPELCO, Bellefonte, USA) was used. SPME and injection of samples were carried out automatically with auto sampler AOC-20 (Shimadzu, Japan). Aliquots of $500 \mathrm{mg}$ of leaves (air-dry; 9\% water content) in capped vials were incubated at $50{ }^{\circ} \mathrm{C}$ for $10 \mathrm{~min}$ prior to piercing through the septum of the vial cap. Adsorption time was $10 \mathrm{~min}$ at $50{ }^{\circ} \mathrm{C}$ for samples. The fiber was withdrawn and transferred into the injection port of the GC. Desorption time was set to $1 \mathrm{~min}$ while the temperature of the injection port was $250^{\circ} \mathrm{C}$.

\section{Gas chromatography-mass spectrometry con- ditions}

Gas chromatography-mass spectrometry (GCMS) analyses were carried out using model GC-2010 gas chromatograph with model GCMS-QP2010 mass spectrometer (Shimadzu, 
Japan), RTX - 5 MS low bleed column $(30 \mathrm{~m} \times 0.25 \mathrm{~mm} \times 0.25 \mu \mathrm{m})$ coated with low polarity $5 \%$ phenyl methylpolysiloxane-95\% dimethylpolysiloxane stationary phase was used for separation of the essential oils. Helium was used as the carrier gas, injection port temperature was set at $230^{\circ} \mathrm{C}$ and the injected sample volume was $1 \mu \mathrm{l}$. Injections were performed in a split mode (split ratio 10:1). The column oven temperature was programmed from $30{ }^{\circ} \mathrm{C}$ to $200{ }^{\circ} \mathrm{C}$ at $5{ }^{\circ} \mathrm{C} / \mathrm{min}$, held at $200{ }^{\circ} \mathrm{C}$ for $2 \mathrm{~min}$ and then programmed to rise at $20^{\circ} \mathrm{C} / \mathrm{min}$ to $280{ }^{\circ} \mathrm{C}$. Kovats' retention indices were determined for each peak from the interpolation of $n$-alkanes retention times at the same temperature gradient. Electron ionization was performed at $70 \mathrm{eV}$. To identify and determine the content of the compounds, total ion current (TIC) signal was recorded as chromatograms.

Table 2 presents the results of three spectrophotometric assays of the total amount of phenolic compounds (TAP), total amount of flavonoids (TAF) and radical scavenging activity (RSA) in leaves of plants. The total amount of phenolic compounds varied from 3380 to $12300 \mathrm{mg} \mathrm{RE} / 100 \mathrm{~g}$ and was the highest at the start of seed ripening vegetation period (sample 7) for Liriodendron tulipifera L. and the lowest for Ginkgo biloba L. in seed ripening vegetation period (sample 3). The TAP values for Liriodendron tulipifera L. leaves were significantly higher than those for Ginkgo bilo$b a$ L. leaves. The highest content of flavonoids was found in Liriodendron tulipifera L. leaves at the start of seed ripening vegetation period (sample 7) (2 $280 \mathrm{mg} \mathrm{RE} / 100 \mathrm{~g}$ ), the lowest content of flavonoids was found in Ginkgo biloba L. at seed ripening vegetation period (sample 3) (1 $110 \mathrm{mg}$ RE/100 g). The flavonoid concentration in Ginkgo biloba L. standardized extract is $192.69 \mathrm{mg} \mathrm{RE} / \mathrm{g}$ [29]. The highest radical scavenging activity was of Liriodendron tulipifera $\mathrm{L}$. at the start of seed ripening vegetation period (sample 7) (14 $020 \mathrm{mg} \mathrm{RE/100} \mathrm{g).}$ The lowest radical scavenging activity was of Ginkgo biloba L. leaves at the end of leaf growth (sample 1) (6 $170 \mathrm{mg} \mathrm{RE/100} \mathrm{g).}$

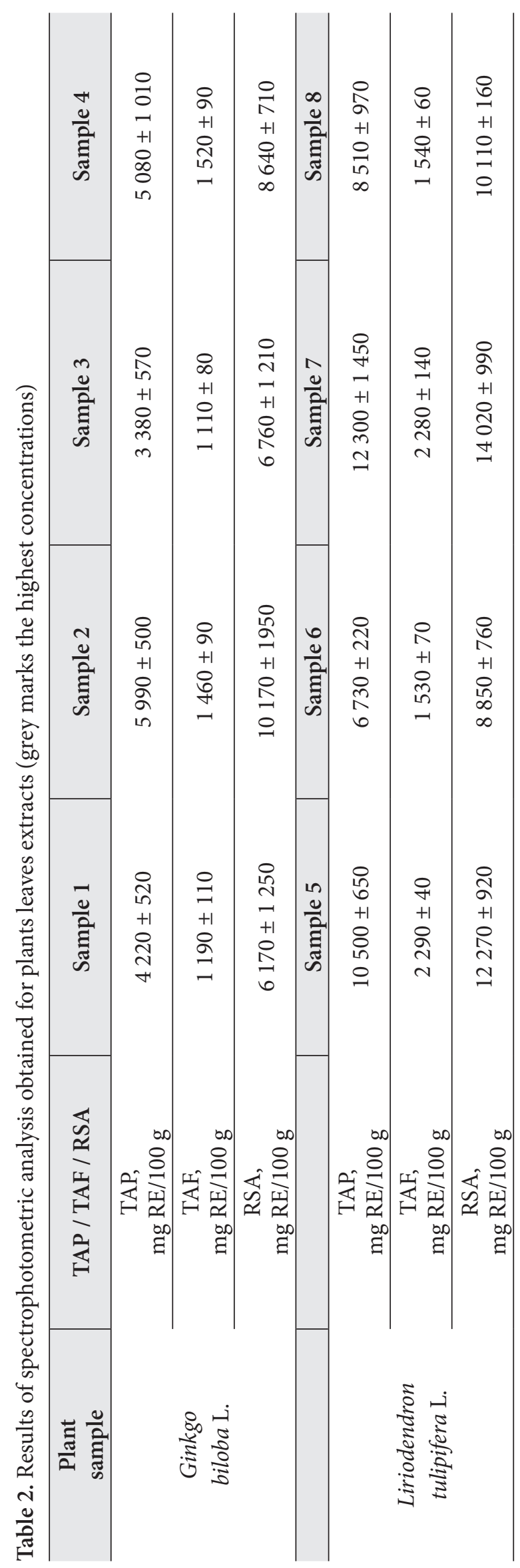




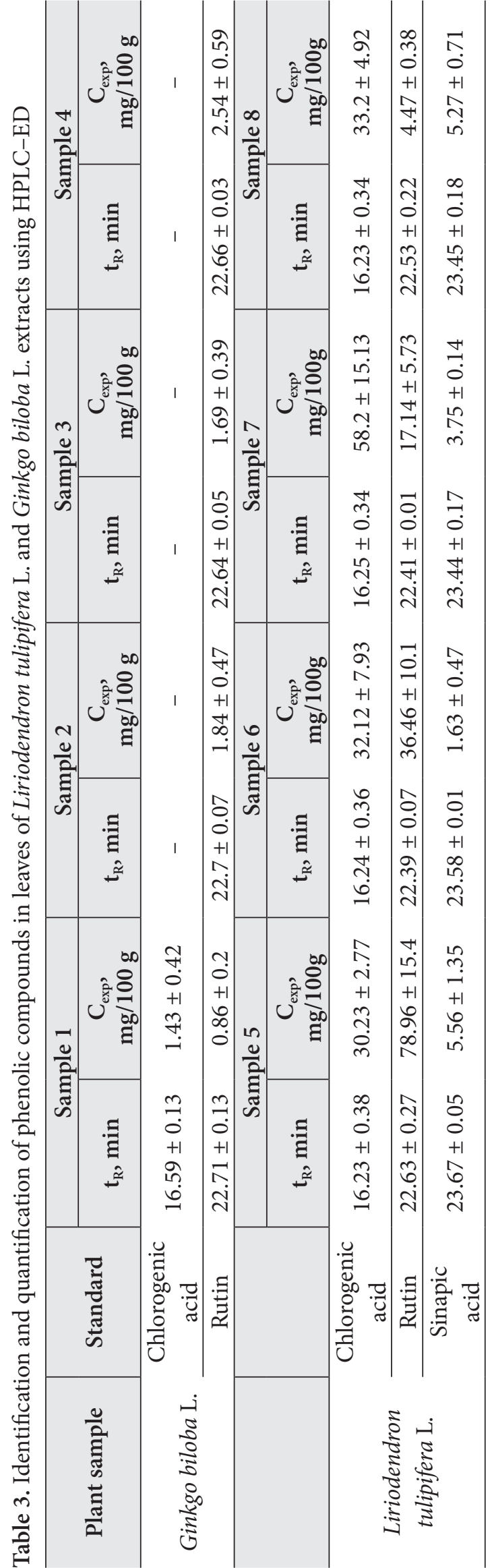

The chromatographic system with the electrochemical detector (HPLC-ED system) was used for a reversed-phase liquid chromatographic evaluation of the phenolic compounds present in plants extracts. Eleven phenolic compounds, namely gallic, chlorogenic, caffeic, ferrulic, syringic, synapic, 3,4-dihydrobenzoic (protocatechuic), 2-hydroxycinamic (o-coumaric) acids, rutin, naringenin, quercetin as external standards were injected into HPLC-ED system for identification and quantification of separated compounds in plants extracts. All standards were injected separately and their retention time was recorded and matched with chromatograms of plants extracts.

The results of quantitative analysis are shown in Table 3. Two phenolic compounds were identified in the extracts of Ginkgo biloba L., namely rutin and chlorogenic acid. Rutin was found in all samples of leaves of Ginkgo biloba L. The highest amount of rutin was in sample 4 (end of leaf growth phase) $(2.54 \mathrm{mg} / 100 \mathrm{~g})$, the lowest was in sample 1 (leaf discolouration phase) $(0.86 \mathrm{mg} / 100 \mathrm{~g})$. Ding et al. have described that rutin is one of the ten major active components (bilobalide, ginkgolides A, B, C, quercetin, kaempferol, isorhamnetin, rutin, quercetin-3- $\beta$ D-glucoside and quercitrin) in Ginkgo biloba L. extract [30].

Rutin, chlorogenic and sinapic acids were found in all samples of leaves of Liriodendron tulipifera L. The highest amount of chlorogenic acid was determined in leaves at start of seed ripening vegetation period (sample 7) $(58.2 \mathrm{mg} / 100 \mathrm{~g})$ and the highest amount of rutin and sinapic acid was found in leaves collected at the end of flowering (sample 5) $(78.96 \mathrm{mg} / 100 \mathrm{~g}$ and $5.56 \mathrm{mg} / 100 \mathrm{~g}$ ). As reported by Sullivan et al. [31], chlorogenic acid is one of the predominant phenolic compounds in Liriodendron tulipife$\mathrm{ra}$ L. leaves, which is in agreement with the results obtained for the same plant cultivated in Lithuania.

The GC-MS method was used to determine the qualitative and quantitative composition of the plants samples. Selection of the operating conditions depends on the specific compound or compound family to be extracted or a matrix of 


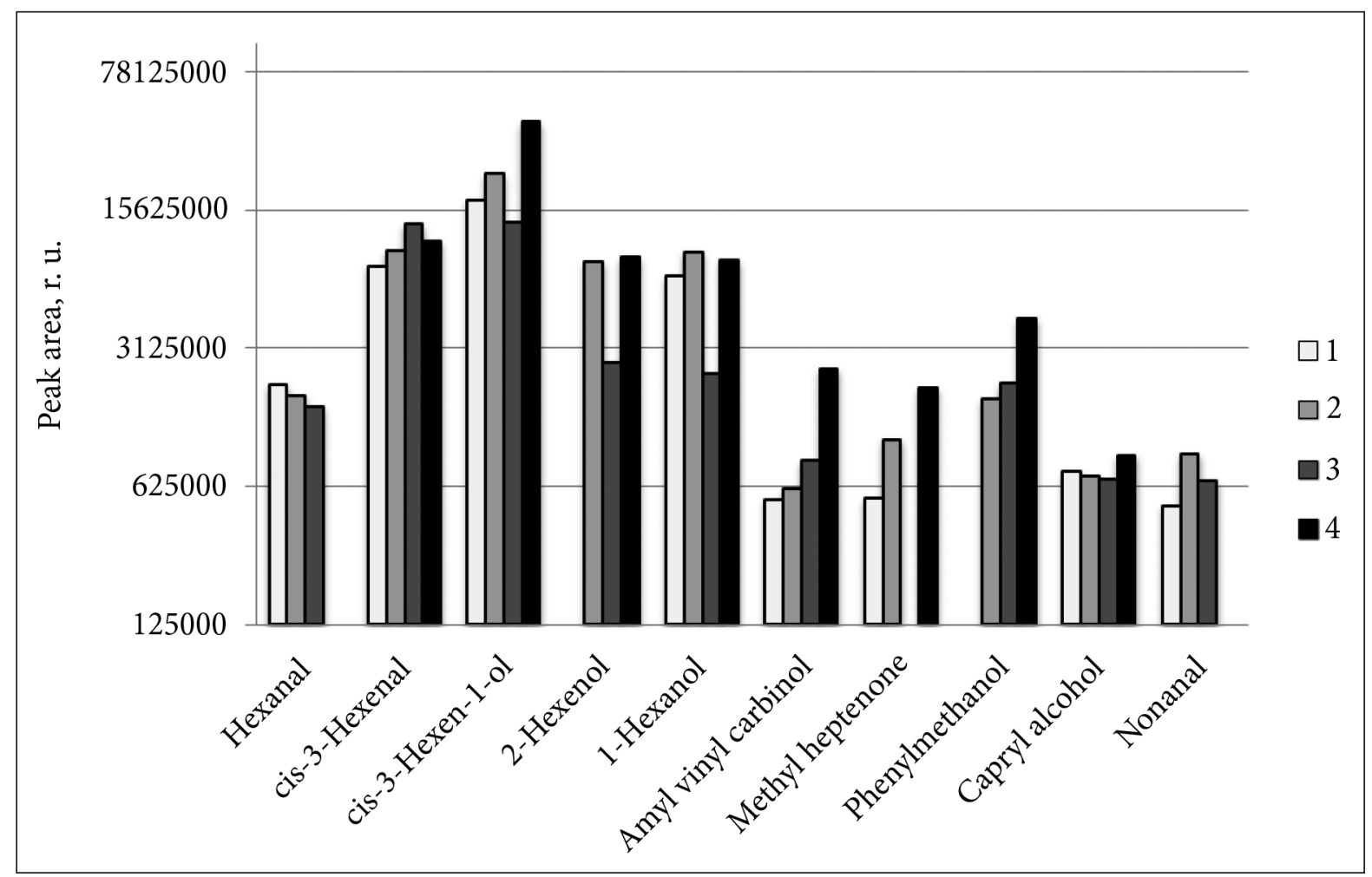

Fig. 1. Composition of the essential oil main compounds of Ginkgo biloba L. leaves of different vegetation periods (samples 1-4) at the optimum headspace SPME conditions (repeatability for peak area: $\mathrm{RSD}=5.15 \%$; for retention time: $\mathrm{RSD}=0.96 \%, \mathrm{n}=5$ )

sample. For more efficient headspace extraction of volatile compounds the dry material of leaves $(500 \mathrm{mg}$ ) was soaked in bidistilled water $(0.5 \mathrm{ml})$ for $15 \mathrm{~h}$, since dry samples resulted in $c a$. seven times lower concentrations of volatile compounds.

In the samples of Ginkgo biloba L. leaves (Fig. 1) 10 volatile compounds were identified using mass spectra library. The highest concentrations were of cis-3-hexen1-ol, cis-3-hexenal, 1-hexanol and 2-hexenol. cis-3-hexen-1-ol, cis-3-hexenal, 1-hexanol are components of the odour of freshly mown grass. Hexanal and nonanal were not found during leaf discolouration vegetation period (sample 4); 2-hexenol and phenylmethanol were not found at the end of leaf growth (sample 1). It is noteworthy that aldehydes hexanal and nonanal were determined in the earlier stages of vegetation (samples 1, 2, 3), however, they were not present in the leaf discolouration phase (sample 4). Some alcohols, i. e. 2-hexenol and phenylmethanol, contrariwise, were not present during the earlier vegetation phase (end of leaf growth, sample 1).

Li et al. [32] have revealed that limonene, isoprene and ocimene are dominating volatile compounds in branches of Ginkgo biloba L. in Shenyang (China). These compounds were not found in analysed leaves samples of Ginkgo biloba L. grown in Lithuania.

In the samples of Liriodendron tulipifera L. (Fig. 2) eleven volatile compounds were identified and quantified. In leaves of Liriodendron tulipifera L. concentrations of cis-3hexenal, 2-hexenol, germacene $\mathrm{D}, \beta$-ocimene and neocembrene were highest. Monocyclic diterpene neocembrene as well as sesquiterpenes $\beta$-selinene and bicyclogermacrene were not determined in the early vegetation phase (end of leaf growth, sample 5). As 


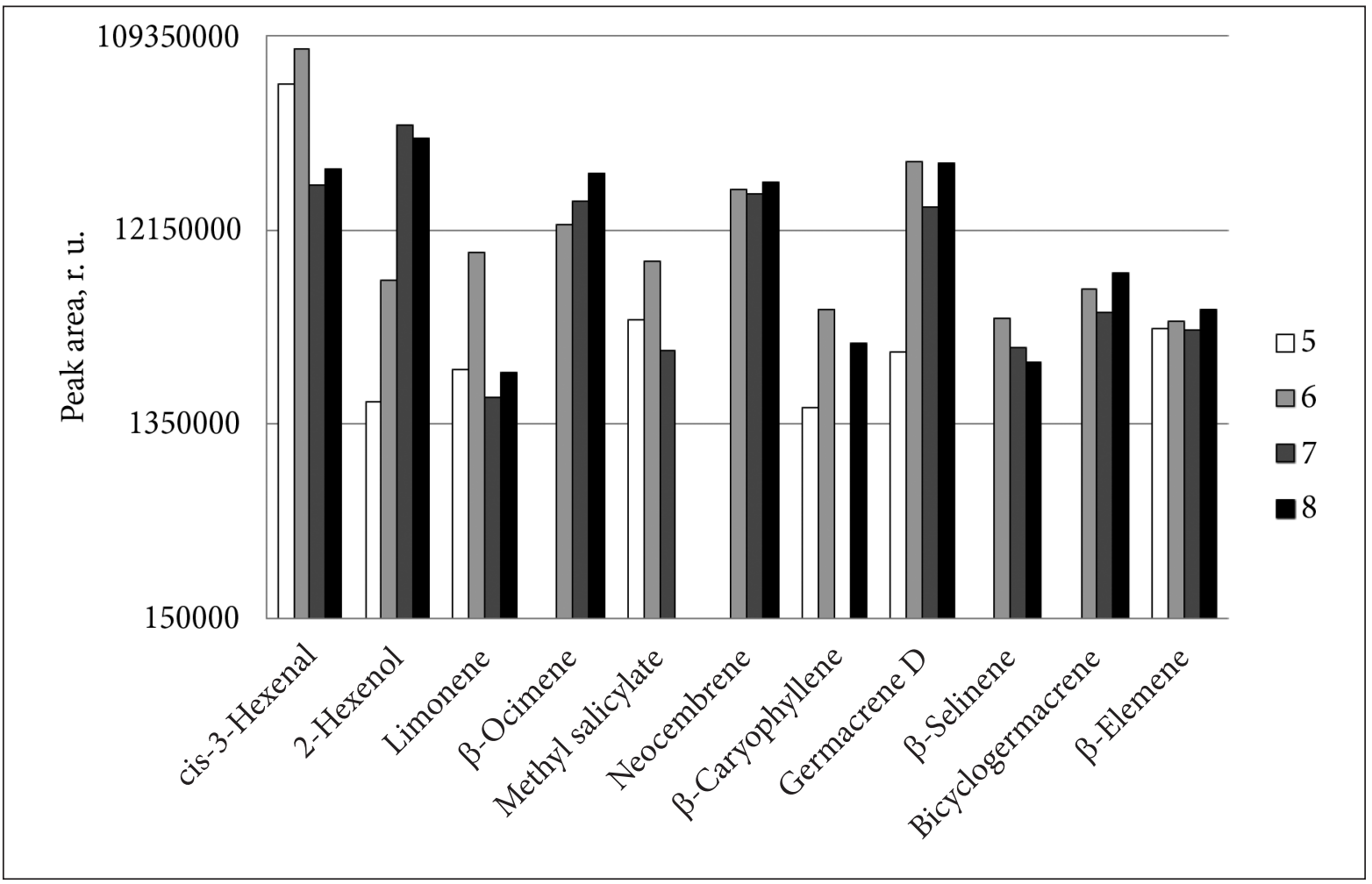

Fig. 2. Composition of the essential oil main compounds of Liriodendron tulipifera L. leaves of different vegetation periods (samples 5-8) at the optimum headspace SPME conditions (repeatability for peak area: $\mathrm{RSD}=5.15 \%$; for retention time: $\mathrm{RSD}=0.96 \%, \mathrm{n}=5$ )

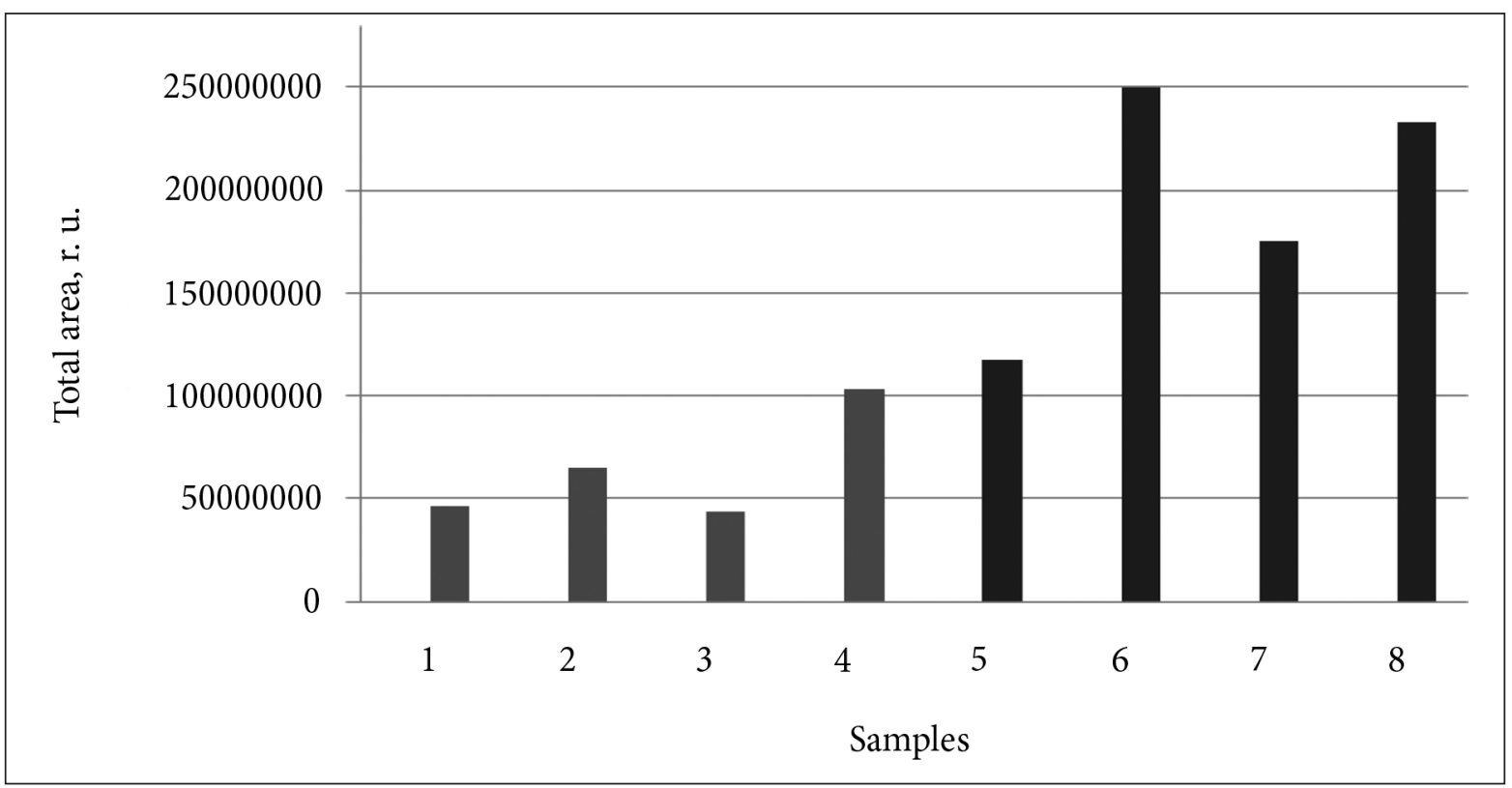

Fig. 3. Concentration of volatile compounds of Liriodendron tulipife$r a \mathrm{~L}$. and Ginkgo biloba L. leaves of different vegetation periods (samples 1-8) at the optimum headspace SPME conditions (repeatability for peak area: $\mathrm{RSD}=5.15 \%$; for retention time: $\mathrm{RSD}=0.96 \%, \mathrm{n}=5$ ) 
reported by Azuma [33], the concentrations of limonene and $\beta$-ocimene are the highest in samples of Liriodendron tulipifera L. collected from native growing places in North America. In all samples of Liriodendron tulipifera L. cis3-hexenal, 2-hexenol, limonene, $\beta$-elemene and germacene $\mathrm{D}$ were determined. cis3-hexenal is an aroma compound with an intense grassy-green odour of freshly cut green grass and leaves. Concentration of volatile compounds in the samples of Liriodendron tulipifera L. was higher than in samples of Ginkgo biloba L. (Fig. 3) during all the vegetation phases investigated. The highest concentration of volatile compounds was at the end of flowering (sample 6) of Liriodendron tulipifera L., more than five times higher than during period of seed ripening (sample 3) of Ginkgo biloba L., where concentration of volatile compounds was the lowest. The highest concentration of volatile compounds in samples of Ginkgo biloba L. was on the period of leaf discolouration (sample 4).

The results obtained allowed us to draw a conclusion that Liriodendron tulipifera L. leaf extracts are stronger in radical scavenging activity compared to Ginkgo biloba L. and accumulate higher amount of phenolic compounds compared to Ginkgo biloba L. A lower concentration of volatile compounds was also determined in Ginkgo biloba L. leaves compared to Liriodendron tulipifera L. leaves.

\section{CONCLUSIONS}

1. It was determined that the highest total amount of phenolic compounds, flavonoids and highest radical scavenging activity are characteristic for Liriodendron tulipifera L. leaves collected at the start of seed ripening (sample 7) vegetation period (total amount of phenolic compounds $12300 \mathrm{mg} \mathrm{RE} / 100 \mathrm{~g}$, total amount of flavonoids $2280 \mathrm{mg} R E / 100 \mathrm{~g}$ and radical scavenging activity $14020 \mathrm{mg}$ $\mathrm{RE} / 100 \mathrm{~g})$. In Ginkgo biloba L. the highest amount of phenolic compounds and radical scavenging activity are determined at the end of leaf growth (sample 2) (total amount of phenolic compounds $5990 \mathrm{mg} \mathrm{RE} / 100 \mathrm{~g}$ and radical scavenging activity $10170 \mathrm{mg}$ RE/100 g).

2 . The qualitative and quantitative analysis of phenolic compounds in extracts of investigated plants leaves using a high performance liquid chromatography system with electrochemical detector and external standards revealed the presence of rutin, chlorogenic and sinapic acids in extracts of Liriodendron tulipifera L. and rutin with chlorogenic acid in methanolic extracts of Ginkgo biloba L.

3. Variation of volatile compounds in the leaf samples depends on plant species and on vegetation period. The greatest qualitative and quantitative variation of volatile compounds was determined through the investigated vegetation phases of Liriodendron tulipifera L. The highest concentration of volatile compounds was found at the end of flowering (sample 6).

Received 25 April 2013

Accepted 20 July 2013

\section{References}

1. Kim Young J, Young Lee J, Young Lee W, Yi Y, Lim Y. Korean J Microbiol Biotech 2010; 38(4): 414-9.

2. Jacobs G, Weber E, Edwards PJ. Divers Distr 2004; 10: 11-9.

3. Middleton JE, Kandaswami C, Theoharides TC. Pharm Rev 2000; 52: 673-751.

4. Sticher O. Planta Medica 1993; 59(1): 2-11.

5. Stiker O, Meier B, Hasler A. Ginkgo biloba; van T. A. E. Beek (ed.); Harwood Academic Publishers: Amsterdam, 2000: 179-202.

6. Van Beek. J Chromat A 2002; 967(1): 21-55.

7. Smith JV, Luo Y. Appl Microbiol Biotech 2004; 64: 456-72.

8. Smith PF, Maclennan K, Darlington CL. J Ethnopharm 1996; 50(3): 131-9.

9. Gertz HJ, Kiefer M. Curr Pharmaceut Design 2004; 10: 261-4. 
10. Nishida S, Satoh H. Life Sci 2003; 72: 2569667.

11. Blumenthal M. Herbal Gram 2001; 51: 69.

12. Mahadevan S, Park Y. J Food Sci 2008; 73(1): 14-9.

13. Ernest E. Brit Medic J 2000; 321(7269): 11335.

14. Škrovankova S, Mišurcova L, Machu L. Advan Food Nutr Res 2012: 75-139.

15. Merkle SA, Sommer HE. Biotech Agric Forest, Trees III. Berlin: Springer-Verlag, 1991; 16: 94-110.

16. Kim TW. Kyo-Hak publishing Co., Ltd. Seoul; 1995: 101.

17. Doskotch RW, el-Feraly FS, Fairchild EH, Huang CT. J Org Chem 1977; 42: 3614-8.

18. Hufford CD, Funderburk MJ, Morgan JM, Robertson LW. J Pharmaceut Sci 1975; 64: 789-92.

19. Sepp-Lorenzino L, Tjaden G, Moasser MM, Timaul N, Ma Z, Kohl NE, Gibbs JB, Oliff A, Rosen N, Scher HI. Prost Cancer Prostat Diseas 2001; 4: 33-43.

20. Chiu ChCh, Chou HL, Wu PF, Chen HL, Wang HM, Chen ChY. J Molec 2012; 17: 435772.

21. Scriber JM, Hsia MTS, Sunarjo P, Lindroth RL. In: G. R. Waller (ed.) Allelochemicals: role in agriculture and forestry. American Chemical Society, Washington, 1987: 439-48.

22. Doskotch RW, Odell TM, Girard L. J Agricult 1981; 1584: 657-66.

23. Chang HC, Chang FR, Wu YC, Lai YH. Kaohsiung J Medic Sci 2004; 20: 365-71.

24. Graziose R, Rathinasabapathy T, Lategan C, Poulev A, Smith PJ, Grace M, Lila MA, Raskin I. J Ethnopharmacol 2011; 133: 26-30.

25. Hsieh TJ, Liu TZ, Chern CL, Tsao DA, Lu FJ, Syu YH, Hsieh PY, Hu HS, Chang TT, Chen CH. Food Chem Toxic 2005; 43: 1117-26.

26. Stankevičius M, Akuneca I, Jakobsone I, Maruška A. J Separ Sci 2011; 34: 1-7.
27. Urbonavičiūte A, Jakštas V, Kornyšova $O$, Janulis V, Maruška A. J Chromat 2006; 1112: 339-44.

28. Brand-Williams W, Cuvelier M, Berset C. Lebensmittel Wissens Chaft und Technologie 1995; 28: 25-30.

29. Stankovic MS, Niciforovic N, Topuzovic M, Solujic S. Biotech Biotechnol Equip 2011; 25: 2222-7.

30. Ding S, Dudley E, Plummer S, Tang J, Newton RP, Brenton AG. Rapid Comm Mass Spectrom 2006; 20: 2753-60.

31. Sullivan JH, Gitz DC, Peek MS, McElrone AJ. Agr Forest Meteor 2003; 120: 219-28.

32. Li D, Shi Y, He X, Chi G, Huang W. Adv Mater Res 2010; 81: 113-6.

33. Azuma H, Toyota M, Asakawa Y, Yamaoka R, Garcia-Franco JG, Dieringer G, Thien LB, Kawano S. Plant Species Biol 1997; 12: 69-83.

\section{Jurgita Mikašauskaitė, Ona Ragažinskienė, Audrius Maruška}

FENOLINIŲ JUNGINIŲ, RADIKALỤ SURIŠIMO AKTYVUMO IR LAKIỤJŲ JUNGINIŲ SUDĖTIES ANALIZE் LIRIODENDRON TULIPIFERA L. IR GINKGO BILOBA L. LAPUOSE SKIRTINGAIS VEGETACIJOS TARPSNIAIS

\section{Santrauka}

Lietuvoje introdukuotų Liriodendron tulipifera L. ir Ginkgo biloba L. rūšių reliktinių augalų palyginamoji fitocheminè analizé iki šiol nebuvo atlikta. Šio tyrimo tikslas - atlikti biologiškai aktyvių junginių, aptinkamų šiuose dviejuose Lietuvoje introdukuotuose augaluose, kompleksinę palyginamąją analizę taikant spektrofotometrinius, chromatografinius ir masių spektrometrijos metodus. Straipsnio autorių žiniomis, iki šiol nebuvo publikuota skirtingose šalyse introdukuotu Liriodendron tulipifera L. ir Ginkgo biloba L. augalu analizès duomenų. Tyrimo metu buvo nustatyta lakiųjų junginių sudètis, radikalu surišimo aktyvumas, fenolinių junginių ir flavonoidų sudètis 
bei bendras kiekis, kaupiamas šių augalų lapuose skirtingais vegetacijos tarpsniais. Pastebèti ženklūs fenolinių junginių kiekybinès ir kokybinès sudèties skirtumai skirtingais šiu augalų vegetacijos tarpsniais. Didžiausi fenolinių junginių kiekiai rasti Liriodendron tulipifera L. lapuose, surinktuose sèklų brendimo pradžioje (12 $300 \mathrm{mg}$ RE/100 g), ir Ginkgo biloba L. lapuose, surinktuose lapų augimo pabaigoje (5 990 mg RE/100 g). Fenolinių junginių kiekybinès ir kokybinès analizės metu nustatyta, kad Liriodendron tulipifera L. ekstraktuose yra chlorogeno ir sinapo rūgščių bei rutino, o Ginkgo biloba L. ekstraktuose - chlorogeno rūgšties ir rutino. Lakiujų junginių sudètis ir koncentracija priklauso nuo augalo rūšies ir vegetacijos tarpsnio. Didžiausia lakiụjų junginių koncentracija nustatyta žydèjimo pabaigos periodu surinktuose Liriodendron tulipifera L. lapuose.

Raktažodžiai: Liriodendron tulipifera L., Ginkgo biloba L., radikalų surišimo aktyvumas, vegetacijos tarpsniai, DPPH, kietafazè mikroekstrakcija 
